\title{
STEM Project-Based Learning Models in Learning Mathematics to Develop 21st Century Skills
}

\author{
Luki Luqmanul Hakim ${ }^{1}$, Yayu Laila Sulatri ${ }^{1}$, Achmad Mudrikah ${ }^{1}$, Deti Ahmatika ${ }^{1}$ \\ \{luqmanhakim@uninus.ac.id, yayu_ls@uninus.ac.id, achmadmudrikah@uninus.ac.id, \\ detiahmatika@fkip-uninus.ac.id\}
}

Universitas Islam Nusantara, Bandung, Indonesia ${ }^{1}$

\begin{abstract}
A this paper discusses the innovation strategy to develop 21st century skills for students through STEM project-based learning models. That is project-based learning by integrating STEM fields, where the teacher through the topics discussed connects science and technology through engineering techniques. In the context of mathematics learning, STEM project-based learning is very potential to provide meaningful learning, can train students' abilities to problem-solving through an integrated project with one or several other scientific fields, in addition to providing students with an experience that mathematics is real benefits for life, and around them.
\end{abstract}

Keywords: STEM project-based learning models, learning mathematics, problemsolving, 21st century skills.

\section{Introduction}

The pattern of education that includes aspects of Science, Technology, Engineering and Mathematics (STEM) in learning in schools can develop learning interest in students [1][2], where students with the STEM approach is expected to have hard skills that are balanced with soft skills, because in the learning process carried out with active learning methods which include communication, collaboration, problem-solving, leadership, creativity, and others. Thus, the purpose of education and the development of quality education must be shifted not only to look for grades and graduation requirements but have a broad understanding that is balanced with good creativity, critical thinking, and problem-solving abilities, or the development of hard skills is balanced with soft skills.

One learning model that supports the development of hard skills and soft skills of students is the project-based learning model. The application of project-based learning in learning science and mathematics from the results of research can improve cognitive learning outcomes [3], shape attitudes and caring behavior towards the environment [4][5], science process skills [6], and effective learning [7][8]. project-based learning is more suitable in interdisciplinary learning because it naturally involves many different academic skills, such as reading, writing, and mathematics and is appropriate in building conceptual understanding through assimilation of different subjects [9], so project-based learning is expected to build 21st century skills and student scientific literacy.

The link between science and technology and other sciences cannot be separated in the study of science and mathematics. The STEM is a discipline that is closely related to each other. Science requires mathematics as a tool in processing data, while technology and 
techniques are applications of science. The STEM approach to learning is expected to produce meaningful learning for students through the systematic integration of knowledge, concepts, and skills. Morrison [2] revealed that the benefits of the STEM approach make students able to solve problems better, innovators, inventors, independent, logical thinkers, and technology literacy.

A more comprehensive way to instill all four disciplines into one another by teaching them as integrated subjects. For example, there is technology, engineering, and mathematics content in science, so science teachers will integrate T, E, and M into S [10][11][12]. Science and mathematics are considered appropriate to become vehicles carrying STEM education because these two subjects are the main subjects in primary and secondary education and become the foundation for students to enter careers in STEM disciplines that are considered fundamentally for technological innovation and economic [13][14].

Research on the integration of STEM in project-based learning on science and mathematics is still rare. The results of Tseng et al.'s research [5] revealed that integrated project-based learning STEM can improve student learning interest, learning becomes more meaningful, helps students in solving problems in real life, and supports future careers. In addition, STEM in project-based learning presents challenges and motivates students because it trains students to think critically, analyze and improve higher-order thinking skills [9][1]. Through STEM learning, students have visible scientific and technological literacy from reading, writing, observing, and doing science so that it can be used as a provision for living in a society and solving problems faced in daily life related to the field of the STEM [11][15].

Based on this background, the researcher considers it necessary to conduct further studies on the application of the STEM project-based learning models in mathematics learning to develop $21^{\text {st }}$ century skills in students.

\section{Method}

This research consists of four phases that define, design, develop, and disseminate called the 4D development model from Thiagarajan et al [16]. Samples in this research consisted of two class in junior high school and three in senior high school classes taken by purposive sampling.

\section{Result and Discussion}

\subsection{Define, Design and Develop Models}

The integration pattern that researchers are trying to develop is incorporating science (S), technology $(\mathrm{T})$, and engineering (E) content into mathematics learning with project-based learning models, as illustrated in Figure 1. 


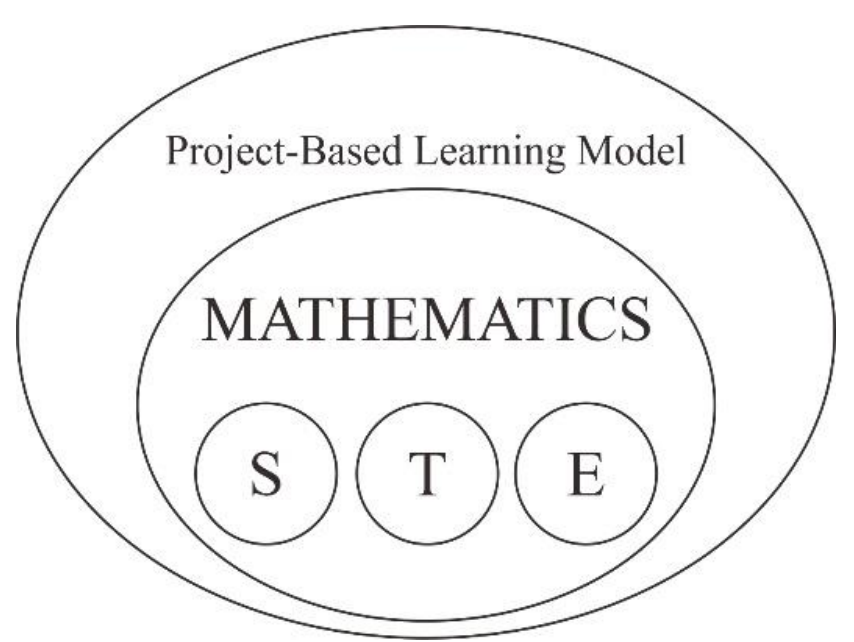

Fig. 1. Development Patterns STEM Project-Based Learning Models

The development of the initial phase of the development of project-based learning models with the STEM is to design unit models of STEM-based learning that are effectively implemented in school settings or outside of school. In this connection, in the field of mathematics education is expected to contribute to the development of integrated mathematics learning unit models of STEM and teaching materials that are tested for their effectiveness based on classroom-based scientific research.

The next phase of development phase includes an analysis of the subject matter content in the applicable mathematics curriculum, then initiating the content learning innovation that integrates science (S), technology (T), and engineering (E), in it with project-based learning models.

The testing phase involves experimental designs to test the effectiveness of mathematics learning with project-based learning models (including learning tools and materials) integrated STEM which was initiated in various school settings.

In accordance with the characteristics of STEM implementation of project-based learning models, the assessment of student learning outcomes focuses on authentic assessment, especially performance assessment [12]. Performance assessment using a rubric designed both for teachers and observers to assess students' performance during learning activities and collaborative work products to reveal the achievement of learning outcomes.

At the beginning of the development of research, researchers expect that students 'learning experiences with STEM project-based learning models in mathematics learning can simultaneously develop students' understanding of science content, technology, engineering, ability to innovate, and problem-solving, soft skills and hard skills, as well as impact furthermore he can develop $21^{\text {st }}$ century skills.

\subsection{Implementation Report}

The implementation of this study consists of three cycles, where each cycle of students is given higher order thinking skills (HOTS) to measure the effectiveness of the application of STEM project-based learning models in mathematics learning in developing learning and innovation skills as part of $21^{\text {st }}$ century skills, as for the results seen in Table 1 below. 
Table 1. The result of applying the models

\begin{tabular}{lcccccc}
\hline \multicolumn{1}{c}{ Category } & \multicolumn{5}{c}{ Junior high school } & \multicolumn{2}{c}{ Senior high school } \\
& \multicolumn{3}{c}{$(n=54)$} & & \multicolumn{3}{c}{$(n=79)$} & \\
& $* \mathrm{C}-1$ & $* \mathrm{C}-2$ & $* \mathrm{C}-3$ & $* \mathrm{C}-1$ & $* \mathrm{C}-2$ & $* \mathrm{C}-3$ \\
\hline Critical thinking & 16,7 & 40,7 & 59,2 & 22,8 & 43,1 & 72,1 \\
Communication & 12,9 & 46,3 & 77,8 & 18,9 & 41,7 & 75,9 \\
Collaboration & 11,1 & 55,5 & 85,2 & 26,6 & 50,6 & 88,6 \\
Creativity & 11,1 & 35,1 & 62,9 & 31,6 & 40,5 & 62,1 \\
Problem-solving & 0,7 & 29,6 & 57,4 & 16,4 & 34,1 & 56,9 \\
$* \mathrm{C}=$ Cycle (\%) & & & & & & \\
\hline
\end{tabular}

Based on Table 1, it can be seen that the implementation of STEM project-based learning models in mathematics learning has not reached the maximum percentage in each cycle, although there is a paradigm shift in the mindset of students in learning activities where students begin to think critically to find out something they do not know, communicate and collaborate with his friends came up with creative ideas in problem-solving given by the teacher and provided learning experiences to apply academic knowledge in the real world.

Another most fundamental finding of the data is the low mindset of students when solving problems when learning collaborates with STEM, it is possible because students are not accustomed to and first experienced, it is in accordance with what was stated by Roberts [11] and Bybee [13] that the integration of STEM in learning must be accustomed to from elementary education so that when entering higher education they are accustomed to being challenged to perform authentic engineering tasks as a complement to learning through project activities that integrate science $(\mathrm{S})$, technology $(\mathrm{T})$, engineering $(\mathrm{E})$, and mathematics $(\mathrm{M})$ in problem-solving.

\section{Concluding Remarks}

The STEM project-based learning model is a pattern of interdisciplinary integration in learning, in which students use science $(\mathrm{S})$, technology $(\mathrm{T})$, engineering $(\mathrm{E})$, and mathematics (M) in a real context with a project-based approach to developing the quality of human resources in problem-solving and to meet the demands of 21 st century skills.

\section{References}

[1] S. Han, R. Capraro, and M. M. Capraro, "How science, technology, engineering, and mathematics (STEM) project-based learning (PBL) affects high, middle, and low achievers differently: The impact of student factors on achievement," Int. J. Sci. Math. Educ., vol. 13, no. 5, pp. 1089-1113, 2015.

[2] M. Stohlmann, T. J. Moore, and G. H. Roehrig, "Considerations for teaching integrated STEM education,” J. Pre-College Eng. Educ. Res., vol. 2, no. 1, p. 4, 2012.

[3] M. Baran and A. Maskan, "The effect of project-based learning on pre-service physics teachers electrostatic achievements," Cypriot J. Educ. Sci., vol. 5, no. 4, pp. 243-257, 2010 . 
[4] A. Kilinç, "Can project-based learning close the gap? Turkish student teachers and proenvironmental behaviours.," Int. J. Environ. Sci. Educ., vol. 5, no. 4, pp. 495-509, 2010.

[5] K.-H. Tseng, C.-C. Chang, S.-J. Lou, and W.-P. Chen, "Attitudes towards science, technology, engineering and mathematics (STEM) in a project-based learning (PjBL) environment," Int. J. Technol. Des. Educ., vol. 23, no. 1, pp. 87-102, 2013.

[6] D. Z. Özer and M. Özkan, "The Effect of the project based learning on the science process skills of the prospective teachers of science," J. Turkish Sci. Educ., vol. 9, no. 3, pp. 131-136, 2012.

[7] K. Cook, G. Buck, and M. P. Rogers, "Preparing biology teachers to teach evolution in a project-based approach,"Sci. Educ., vol. 21, no. 2, pp. 18-30, 2012.

[8] F. Movahedzadeh, R. Patwell, J. E. Rieker, and T. Gonzalez, "Project-based learning to promote effective learning in biotechnology courses," Educ. Res. Int., vol. 2012, 2012.

[9] R. M. Capraro, M. M. Capraro, and J. R. Morgan, STEM project-based learning: An integrated science, technology, engineering, and mathematics (STEM) approach. Springer Science \& Business Media, 2013.

[10] W. E. Dugger, "Evolution of STEM in the United States," in 6th Biennial International Conference on Technology Education Research in Australia retrieved from http://www. iteea. org/Resources/PressRoom/AustraliaPaper. pdf, 2010.

[11] A. Roberts, "A justification for STEM education," Technol. Eng. Teach., vol. 71, no. 8, pp. 1-4, 2012.

[12] R. W. Bybee, The case for STEM education: Challenges and opportunities. NSTA press, 2013.

[13] R. W. Bybee, “Advancing STEM education: A 2020 vision," Technol. Eng. Teach., vol. 70 , no. 1 , p. $30,2010$.

[14] E. M. Reeve, "Implementing science, technology, mathematics and engineering (STEM) education in Thailand and in ASEAN," Rep. Prep. Inst. Promot. Teach. Sci. Technol., 2013.

[15] T. Mayasari, A. Kadorahman, and D. Rusdiana, "Pengaruh pembelajaran terintegrasi science, technology, engineering, and mathemathics (STEM) pada hasil belajar peserta didik: Studi meta analisis," Pros. Semnas Pensa VI "Peran Literasi Sains, vol. 20, 2014.

[16] S. Thiagarajan, D. S. Semmel, and M. I. Semmel, Instructional Development for Training Teachers of Exceptional Children: A Sourcebook, no. Mc. Bloomington: Center for Innovation in Teaching the Handicappe, Indiana University, 1974. 